\title{
Epigeal fauna and soil attributes in a cover-cropped organic vegetable system
}

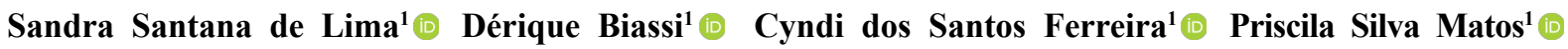 \\ Lucas Vasconcelos Rocha ${ }^{1}$ (i) Marcos Gervasio Pereira ${ }^{1^{*}}$ (i) Everaldo Zonta ${ }^{1}$ (i)
}

${ }^{1}$ Universidade Federal Rural do Rio de Janeiro (UFRRJ), Instituto de Agronomia, Departamento de Solos, 23897-000, Seropédica, RJ, Brasil. E-mail: mgervasiopereira01@gmail.com. ${ }^{*}$ Corresponding author.

\begin{abstract}
This study assessed the effect of cover crop biomass on the epigeal fauna of an organic eggplant (Solanum melongena L.) cropping system. A randomized block design was used, with four cover crop treatments: brachiaria, crotalaria, millet, and cocktail (brachiaria, crotalaria and millet). The epigeal faunal indices were determined at each plot. The epigeal fauna of a secondary forest site was also assessed for comparison. Epigeal individuals were collected using pitfall traps at two sampling periods (110 and 180 days after mowing cover crops). Soil samples were collected for determination of physical and chemic properties. 2032 individuals were captured in the first sampling and 3806 individuals in the second. The highest values of wealth in the first collection were observed in the millet and cocktail areas. Cluster analysis showed similarity of epigeal faunal groups between millet and brachiaria plots at the first sampling and between cocktail and crotalaria sites at the second sampling. Co-inertia analysis showed a significant covariance between epigeal fauna at the second sampling and soil properties. The cover crops management had a beneficial influence on the activity, wealth and ecological indexes, in both sampling periods. The positive association observed between epigeal faunal groups and soil physical and chemical properties demonstrates the efficiency of cover crops in improving soil quality in organic cropping systems.
\end{abstract}

Key words: soil fauna, bioindicators, conservationist management.

Fauna epígea e atributos do solo sob manejo com plantas de cobertura em cultivo orgânico

RESUMO: O objetivo deste estudo foi avaliar o efeito da fitomassa de diferentes plantas de cobertura no desenvolvimento da comunidade da fauna epígea em área de cultivo orgânico de berinjela (Solanum melongena, L.). Foi adotado delineamento em blocos ao acaso, com quatro tratamentos de plantas de cobertura: braquiária, crotalária, milheto e coquetel (crotalária, braquiária e milheto), além de uma área de floresta secundária (FR). A fauna epígea avaliada por meio de armadilhas do tipo "pitfall traps" em dois periodos de coletas, aos 110 dias e aos 180 dias, após o corte das plantas de coberturas. Foram coletadas amostras de solo para análise de atributos fisicos e químicos. Foram capturados 2032 individuos na primeira coleta e 3806 individuos na segunda coleta. Os maiores valores de riqueza na primeira coleta foram observados nas áreas milheto e coquetel. A análise de agrupamento mostrou similaridade dos grupos da fauna epígea entre o milheto e braquiária na primeira amostragem e entre o coquetel e crotalária na segunda amostragem. A co-inércia evidenciou covariância significativa entre a fauna epígea da segunda coleta e os atributos do solo. O manejo com plantas de coberturas influenciou de forma benéfica a atividade, riqueza e índices ecológicos, em ambos os periodos de amostragens. A associação positiva entre grupos da fauna e os atributos físicos e químicos mostram a eficiência das plantas de coberturas em cultivo orgânico na promoção de melhorias da qualidade do solo.

Palavras-chave: fauna do solo, bioindicadores, manejo conservacionista.

\section{INTRODUCTION}

The growing concern of farmers about sustainability and environmental degradation has led to the adoption of no-till cropping practices. Notill farming encompasses a variety of technological approaches to sustainable agriculture that aim to minimize soil degradation and organic matter losses, thereby reducing the use of fertilizers and additives (ANDRADE et al., 2018). Vegetable cultivation it is considered an environmentally and economically suitable alternative for organic cultivation, as it preserves soil organisms and increases the soil organic matter levels (TIVELLI et al., 2010). Cover crops are used in no-till systems as a means to generate green manure and enhance nutrient cycling (TORRES 
et al., 2008). Moreover, cover crops contribute to soil protection and conservation (BESEN et al., 2018) by restoring soil fertility, enhancing physical and chemical attributes, stimulating biological nitrogen fixation, minimizing erosion, reducing soil temperature, and increasing moisture (BARROS et al., 2013; BRUNO et al., 2017).

The most common species used as cover crops in rotation or intercrop systems belong to the Fabaceae (vegetables) and Poaceae (grasses) families (REDIN et al., 2016). Green manure application and no-tillage improve soil biological activity (GAZOLA et al., 2017). By increasing soil moisture content, cover crop residues reduce temperature fluctuations, providing a favorable environment for the growth, activity, and survival of soil organisms (REDIN et al., 2016; MORAES et al., 2016). Organic management practices are in line with the premise of no-till farming and may result in great benefits to the soil invertebrate community.

The positive effects of cover crops on soil fauna (BLANCHART et al., 2006) increase decomposition rates and nutrient cycling, probably persisting into the main crop phase. Because of soil fauna is sensitive to soil management practices (BARETTA et al., 2014) these organisms can be used as indicators of soil quality, as changes generated by land use affect population levels (CASARIL et al., 2019). The ecosystem services provided by epigeal fauna underscore the importance of monitoring the abundance and diversity of such communities.

The number of studies showing clear linkages between soil fauna and crop yield is very limited (JERNIGANA et al., 2020), mainly evaluating the use of cover crops. In this study, it was hypothesized that the abundance and diversity of faunal groups vary according to soil quality and the type of cover crop used in organic eggplant (Solanum melongena L.) systems. Thus, we aimed to (i) assess the effects of different green manure crops on the development of epigeal fauna and (ii) understand the relationship between epigeal fauna and soil quality in an organic eggplant farming system.

\section{MATERIALS AND METHODS}

The study was conducted at Sítio do Sol, a certified organic farm located in Seropédica, Rio de Janeiro State, Brazil, located in the coordinates $22^{\circ}$ 49' 19,79" S e 43 44' 16,43" W. The soil classified as Argissolo Amarelo (Ultisol), with a sandy-clayey texture, according to Biassi (2018). The climate according Köppen (1980) classification, shows rains concentrated in the period from November to March, average annual precipitation of $1,213 \mathrm{~mm}$ and average annual temperature of $24,5^{\circ} \mathrm{C}$ (Figure 1).

The study area corresponds to an area of $15 \times 20$ meters, with plots of $1.5 \times 2.5 \mathrm{~m}$, divided into 4 blocks. The experiment was performed according to a randomized block design, with four replications of four cover crops. Treatments were as follows: Brachiaria (Brachiaria ruziziensis R. Germain \& Evrard), crotalaria (Crotalaria juncea Linnaeus), millet (Pennisetum americanum (L.) K. Schum), and cocktail (mixture of the three cover crops). A secondary forest site was included for comparison. Cover crop seeds were sown in November 2016 and grow until full flowering (March 2017). When plants reached this stage, plots were mowed and plant residues left on the soil surface. Eggplant (Solanum melongena Linn) with the hybrid cultivar "Ciça F1", was planted after implementation of the no-till system, without adding any agrochemicals. In half of the plots, the straw was left on the surface and in the other half, the straw was incorporated into the soil, the study being carried out only in the plots without soil overturning, which resulted in an increase in the distance between treatments.

Epigeal faunal communities were sampled in two periods, the first at 110 days after mowing (June 2017, shortly after eggplant planting) and the second at the end of the eggplant cycle (September 2017, circa 180 days after mowing), one sampling point for the epigeal fauna is established in each plot. Epigeal individuals were sampled using pitfall traps, after five days, the traps were collected and taken to the laboratory (AQUINO et al., 2006). Trapped individuals were examined under a stereomicroscope, identified at the order, class, or family level, and quantified. Identification was performed according to PEREIRA et al. (2018). All identified organisms were registered in the National System of Management of the Genetic Heritage SisGen, under the registration number $n^{\circ}$ AD6AB8B.

At all treatment plots and the forest site, soil samples were collected from the $0-5 \mathrm{~cm}$ depth for determination of soil moisture, temperature, bulk density, $\mathrm{pH}$ in water, $\mathrm{Ca}^{2+}, \mathrm{Mg}^{2+}, \mathrm{Al}^{3+}, \mathrm{K}^{+}$, and $\mathrm{P}$, and calculation of CEC (DONAGEMA et al., 2011) and total organic carbon (TOC) (YEOMANS \& BREMNER, 1988). Nitrogen $(\mathrm{N})$ was determined by the Dumas combustion method using a Rapid N Cube (Elementary ${ }^{\circledR}$ ) analyzer (KEENEY \& BREMNER, 1967).

Epigeal fauna data are presented as number of individuals per trap per day and standard error. Faunal communities were compared using the 


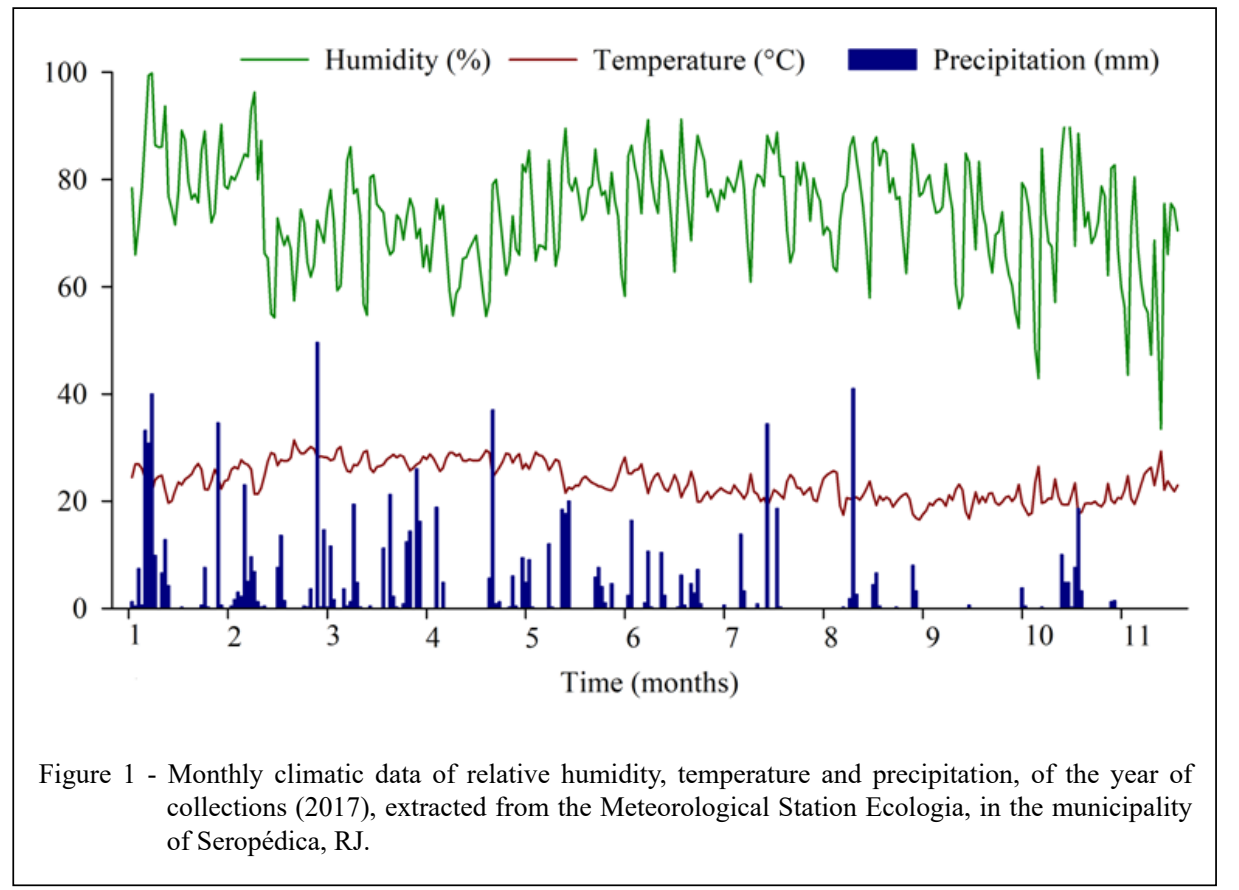

Shannon diversity index $\left(H^{\prime}=-\Sigma p_{i} \cdot \log p_{i}\right.$, with $p_{\mathrm{i}}=$ $n / n$, where $n_{\mathrm{i}}$ is the density of group $i$ and $n$ is the sum of the density of all groups) and Pielou evenness index $\left(J^{\prime}=\right.$ $\mathrm{H}^{\prime} / \log R$, where $R$ is the richness of taxonomic groups).

Cluster analyses were used to measure the similarity between epigeal faunal communities at different sites. Hierarchical cluster analysis was performed by using the clust function in R software (R DEVELOPMENT CORE TEAM, 2019). A matrix was constructed from abundance data of epigeal faunal groups and subjected to a nonmetric multidimensional scaling (NMDS) procedure to visualize the similarity between experimental sites. Co-inertia analysis was performed to assess the covariance and similarity between epigeal faunal groups and soil physical and chemical properties. In this approach, we used Monte Carlo-based permutational multivariate analysis of variance (PERMANOVA) to compare observed statistics with random data permutations. Multivariate analyses were performed using the ade4 package in R software (DRAY et al., 2007; R DEVELOPMENT CORE TEAM, 2019).

\section{RESULTS}

A total of 2032 individuals were captured at the first sampling and 3806 at the second sampling. Epigeal individuals were classified into 11 taxonomic groups, mainly at the class and order levels. At first sampling, performed 110 days after mowing, there was no difference in total epigeal faunal activity between sites (Figure 2A). However richness, differed between sites, with higher values observed in plots under millet, cocktail, and reference forest (Figure 2B). No differences in epigeal faunal activity or richness were observed at second sampling (Figure 2C and D).

Cluster analysis of the relative frequency of epigeal faunal groups collected on the first sampling occasion identified four groups (Figure 3A). The first was formed by millet and brachiaria plots, which shared a high frequency of Collembola individuals (Poduromorpha and Entomobryomorpha). Plots under crotalaria were characterized by a high representation of Collembola groups and an even higher frequency of Coleoptera. The cocktail site, in addition to a high frequency of the aforementioned groups, had a high representation of Acari and Araneae. The forest site was placed on a separate branch, far from cultivated sites; although, taxonomic groups were more evenly distributed, there was a higher frequency of Coleoptera and Formicidae.

Cluster analysis of data from the second sampling occasion (Figure 3B) revealed similarities between cocktail and crotalaria plots, characterized by a predominance of Formicidae and Entomobryomorpha groups. The epigeal fauna of sites under grasses (millet and brachiaria) was dominated by Formicidae, followed by Entomobryomorpha, 


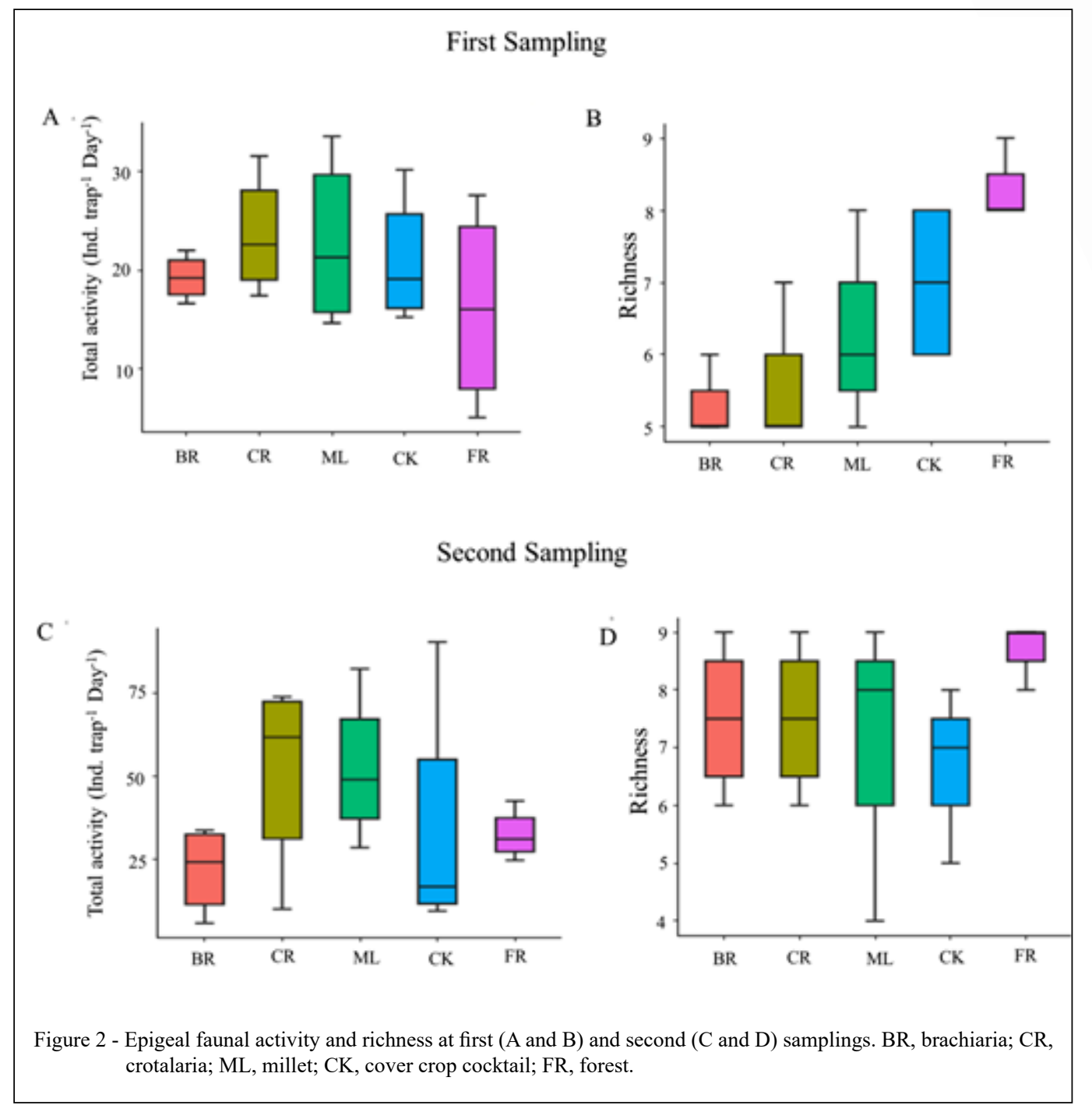

Isopoda, and Coleoptera. The forest site, with a greater representativeness of Symphypleona, was again plotted separately from cultivated sites.

At the first sampling, all cover crop sites showed very similar ecological indices (Table 1). The Shannon diversity index ranged from 1.66 (millet) to 1.75 (crotalaria), whereas the Pielou evenness index varied from 0.46 (millet) to 0.57 (brachiaria). It is noteworthy that the forest site had better values for both indices $\left(H^{\prime}=2.83, J^{\prime}=0.71\right)$. With the exception of brachiaria, all sites had lower diversity and evenness values at the second sampling, including the forest site.

NMDS analyses and PERMANOVA of epigeal faunal groups placed cover-cropped sites separate from the forest site in the first sampling period
(Figure 4A). However, at second sampling, managed and forest sites were similar (Figure 5B). Co-inertia analysis showed a significant covariance $(p=0.003$, $\mathrm{RV}$ coefficient $=46.75 \%$ ) between epigeal faunal groups and chemical soil attributes ( $0-5 \mathrm{~cm}$ depth) at first sampling (Figure 5). Orthoptera and Poduromorpha were positively associated with $\mathrm{P}$ content; species richness with TOC; and Chilopoda, Coleoptera, and Araneae with CEC and N content. Entomobryomorpha was positively associated with moisture and Formicidae with soil density.

\section{DISCUSSION}

The high total number of epigeal fauna at first sampling revealed that cover cropping favored

Ciência Rural, v.51, n.8, 2021. 


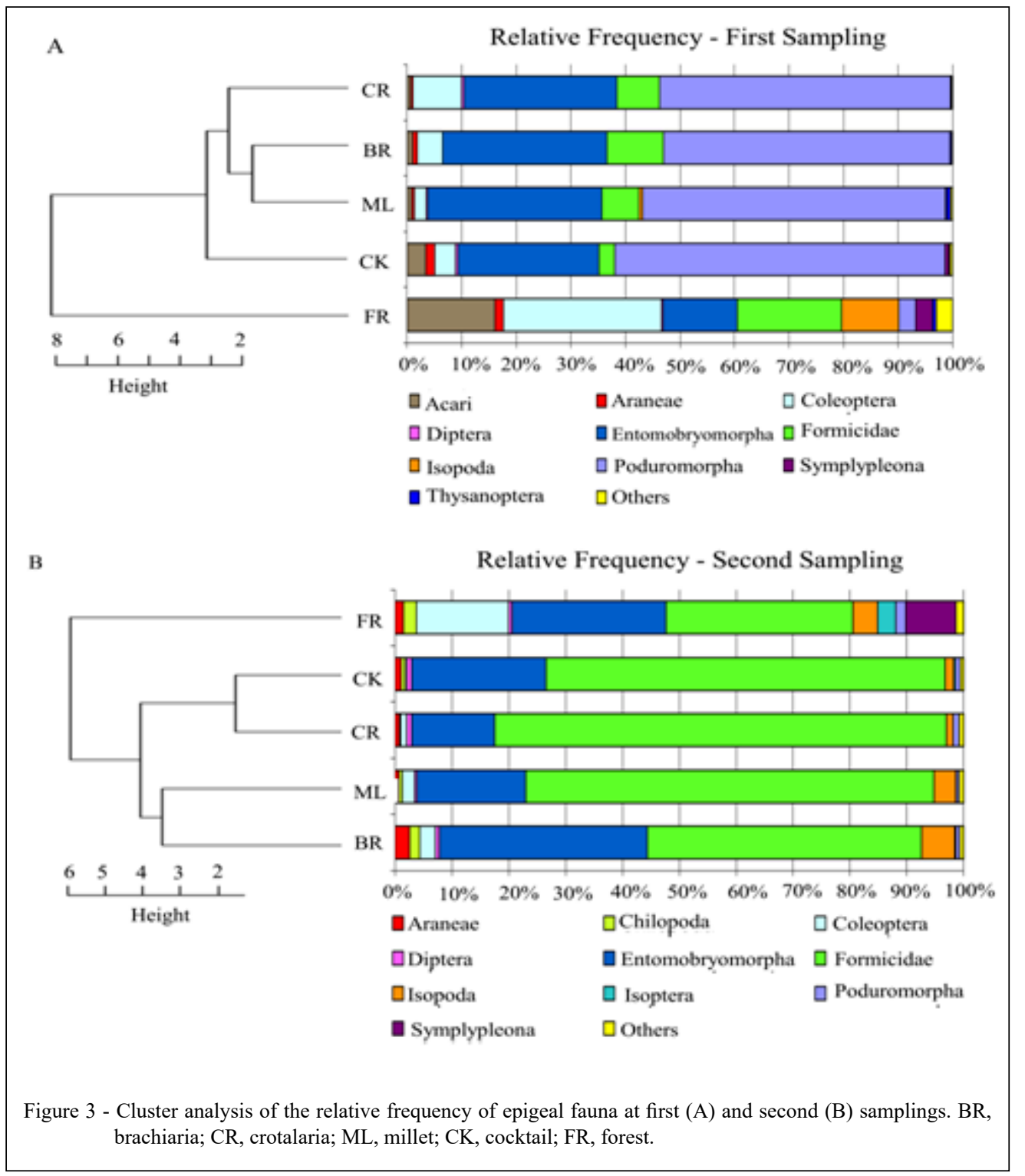

invertebrate development. Faunal abundance responded positively to the use of cover crops, as this management practice improves soil conditions (SCORIZA et al., 2016; ALMEIDA et al., 2016). Cover crops contributed to soil moisture and temperature stability and provided a constant food source, favoring faunal development. However, it is worth mentioning that the results might have been affected by soil management practices and sampling period, considering the higher precipitation level in the first sampling, in relation to the second (Figure 1). SILVA et al. (2012) assessed epigeal fauna in cover crop systems at 50 (fully developed plants), 100 (reproductive phase), and 150 days (end of the crop cycle) and observed a decrease in abundance from the first to the second sampling. We suggest attributed these findings to the type of cover crop and stage of plant development.

Farmers can increase agricultural yield and improve soil, water, and environmental quality by selecting adequate cover plant species and applying good management strategies. In this study, no differences in faunal activity or richness were observed between treatments at any of the sampling periods. It can be inferred that cover crops combined with climatic conditions had similar effects on faunal 
Table 1 - Ecological indices of epigeal fauna sampled from soils under organic cover crops or secondary forest.

\begin{tabular}{|c|c|c|c|c|}
\hline Treatment & Shannon & Pielou & Shannon & Pielou \\
\hline & \multicolumn{2}{|c|}{--------------------------First sampling------------------------ } & \multicolumn{2}{|c|}{-------------------------Second sampling------------------------ } \\
\hline Brachiaria & 1.72 & 0.57 & 1.91 & 0.58 \\
\hline Crotalaria & 1.75 & 0.55 & 1.06 & 0.29 \\
\hline Millet & 1.65 & 0.46 & 1.37 & 0.38 \\
\hline Cocktail & 1.68 & 0.51 & 1.27 & 0.37 \\
\hline Forest & 2.83 & 0.71 & 2.55 & 0.67 \\
\hline
\end{tabular}

activity and richness. Similar results were observed by SCORIZA et al. (2016) and ALMEIDA et al. (2016), who reported no differences in faunal richness between plots with different cover crops. SCORIZA et al. (2016) attributed the findings to the short time of cover crop establishment and the similarity of environmental conditions provided by cover crops.

Our results showed that epigeal faunal richness under millet and cocktail was similar to that of the reference site at the first sampling, suggesting that these cover crops promoted better conditions, such as shelter and food availability, for faunal development than crotalaria and brachiaria. Conversely, at second sampling, richness did not differ between reference and experimental sites. This fact might be associated with the degree of decomposition of plant residues at the time of sampling. Cover crops can stimulate faunal activity because they provide organic matter to soil, increase soil $\mathrm{C}$ contents, and help maintain soil temperature and moisture (KASPAR \& SINGER, 2011; BESEN et al., 2018).

The similarity between clusters at the first sampling might have been influenced by the $\mathrm{C} / \mathrm{N}$ ratio of cover crops. In general, grasses (millet and brachiaria) have a $\mathrm{C} / \mathrm{N}$ ratio of $40: 1$ at full flowering, and legumes (crotalaria) of 20:1 (MONEGAT, 1991). Millet and brachiaria were clustered together at both samplings probably because of the similarity between plants: both are $\mathrm{C}_{4}$ grasses, have vigorous root systems, and promote litter accumulation on the soil surface, favoring faunal communities. At the second sampling, crotalaria and cover crop cocktail were clustered for their similarity in coverage. It suggests that crotalaria provided more benefits to soil organisms.

Among the groups of epigeal fauna, the Collembola was the most frequent group at all plots at the first sampling. At the second sampling (180 days after mowing), Formicidae predominated at all

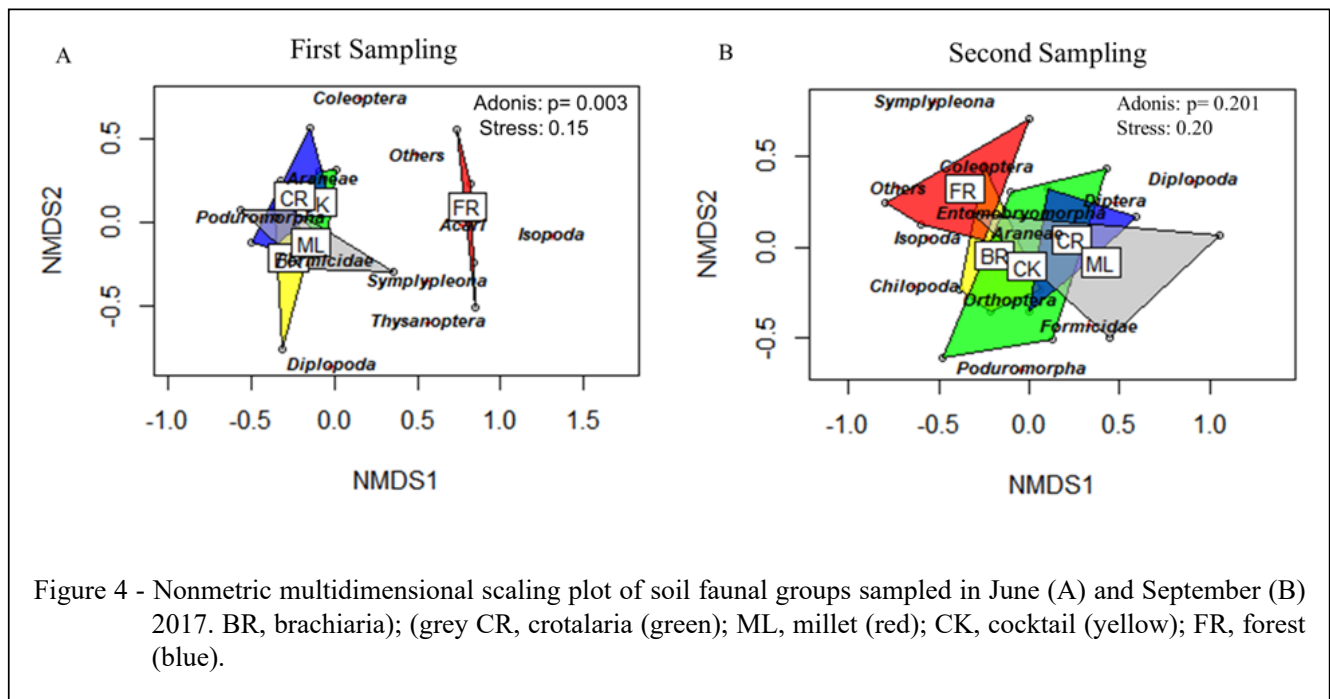

Ciência Rural, v.51, n.8, 2021. 

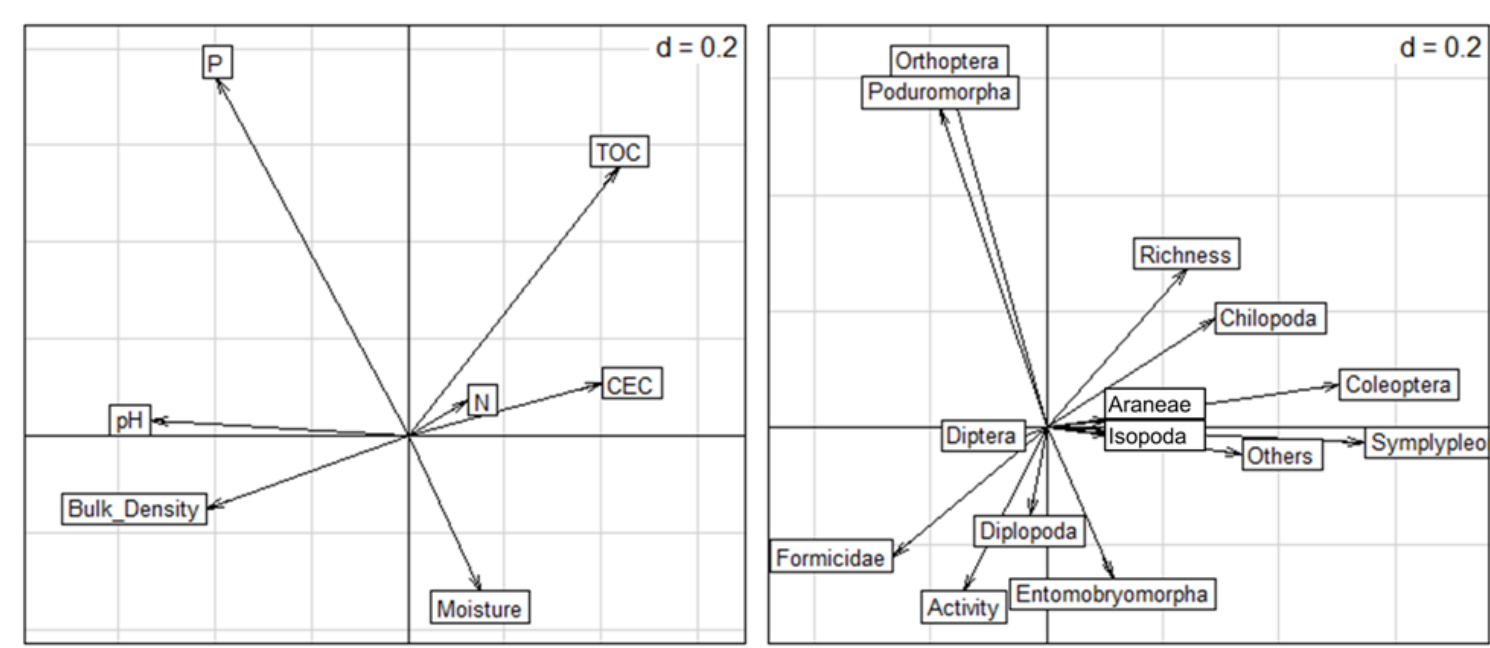

Figure 5 - Co-inertia analyses of (a) soil chemical properties at the $0-5 \mathrm{~cm}$ depth and (b) epigeal faunal groups. Variance explained by Monte Carlo permutation test $=46.75 \%, \mathrm{p}<0.003$. TOC, total organic carbon; CEC, cation-exchange capacity

experimental plots. This difference might be related to the degree of plant decomposition and climate conditions. At the second sampling, plant residues were more decomposed, which reduced shelter availability, and temperatures were higher, favoring more resistant organisms, such as Formicidae, in detriment to more sensitive individuals, such as Collembola. In the study of SCORIZA et al. (2016), Formicidae was more frequent than Collembola at the first sampling, and the frequencies of both groups were lower at the second sampling.

The ecological indices of epigeal fauna at both sampling periods demonstrate that cover crops provided similar conditions for faunal development, particularly at the first sampling, when Shannon and Pielou indices were similar between plots. Ecological indices were lowest for the millet plot because of the high occurrence of Collembola (Poduromorpha and Entomobryomorpha). At the second sampling, Shannon and Pielou indices were highest for the brachiaria plot, resulting from the high diversity of faunal groups, and lowest for the crotalaria plot, because of the predominance of Formicidae.

The faunal groups mentioned above are key players in soil processes, which makes them important indicators of soil quality. Collembola, along with other soil invertebrates, participate in decomposition processes, contributing to nutrient cycling (MAUNSELL, 2012). However, the abundance of these organisms is influenced by soil organic matter (BARTZ et al., 2014). Members of the family Formicidae are detritivores (BROWN et al., 2015) and nest builders (promoting soil aeration) that carry out important ecological functions, such as herbivory, nutrient cycling, physical structuring, and chemical modification (CREPALDI et al., 2014).

NMDS analysis (Figure 4) indicated that invertebrate community proliferation was greatest at the second sampling (180 days after mowing). At first sampling (110 days after mowing), a significant difference was observed between experimental plots and the reference site. Time may have been a determining factor in green manure decomposition and mineralization. Thus, at 180 days after plant mowing, the conditions were favorable to faunal development, as no differences were observed between the reference site and plots treated with green manure (brachiaria, cocktail, crotalaria, and millet).

A significant covariance was observed between epigeal fauna and soil attributes (Figure 5), indicating that cover crops were effective in promoting faunal development and enhancing soil properties. The groups Orthoptera, Poduromorpha, and total richness were positively associated with TOC, an indication that cover crops provide favorable conditions for the growth of soil fauna (BARETTA et al., 2014; MORAES et al., 2016) that participate in litter decomposition and nutrient cycling. Conversely, the groups Chilopoda, Coleoptera, and Araneae were 
associated with CEC and N content. It is important to highlight that soil chemical attributes are influencing the presence of organisms that are crucial for the ecological control of natural enemies, as Chilopoda, Coleoptera, and individuals that play an important role in the food chain as Araneae (predators).

The positive association of Entomobryomorpha with soil moisture supports that cover crops benefit organisms that are sensitive to moisture conditions, as is the case of Collembola. The association of Formicidae with soil density may be directly related to the activity of this group as ecosystem engineers, which, according to LAVELLE et al. (1997), positively influences soil physical and chemical attributes.

\section{CONCLUSION}

The management with cover crops had a beneficial influence on the activity, wealth and ecological indexes, in both sampling periods.

The presence of detritivorous groups (Collembola and Formicidae) more frequently affected the similarities between the areas with cover plants in both sampling periods.

The positive association between faunal groups and soil physical and chemical properties at second sampling showed that cover crops are effective in improving soil quality in organic farming systems.

\section{ACKNOWLEDGEMENTS}

This study was financed by the Coordenação de Aperfeiçoamento de Pessoal de Nível Superior (CAPES, finance code 001). The authors thank Fundação de Amparo à Pesquisa do Estado do Rio de Janeiro (FAPERJ) and the Conselho Nacional de Desenvolvimento Científico e Tecnológico (CNPq).

\section{DECLARTION OF CONFLICT OF INTEREST}

The authors declare no conflict of interest. The founding sponsors had no role in the design of the study; in the collection, analyses, or interpretation of data; in the writing of the manuscript, and in the decision to publish the results.

\section{AUTHORS' CONTRIBUTIONS}

All authors contributed equally for the conception and writing of the manuscript. All authors critically revised the manuscript and approved of the final version.

\section{REFERENCES}

ANDRADE, A. T. et al. Desafios do sistema plantio direto no Cerrado. Informe Agropecuário, v.39, n.302, p.18-26, 2018.
AQUINO, A. M. et al. Recomendações para coleta de artrópodes terrestres por armadilhas de queda (Pitfall Traps). 2006. Circular Técnica 18. Available from: <https://www.infoteca.cnptia. embrapa.br/infoteca/bitstream/doc/628430/1/cit018.pdf $>$. Accessed: Jan. 22, 2020.

BARETTA, D. et al. Soil fauna and its relation with environmental variables in soil management systems. Revista Ciência Agronômica, v.45, n.5, p.871-879, 2014. Available from: $<$ https://doi.org/10.1590/S1806-66902014000500002>. Accessed: Jun. 12, 2020.

BARROS, D. L. et al. Plantas de cobertura e seus efeitos na cultura em sucessão. Bioscience Journal, v.29, n.2, p.308-318, 2013.

BARTZ, M. L. C. et al. The influence of land use systems on soil and surface litter fauna in the western region of Santa Catarina. Revista Ciência Agronômica, v.45, n.5, p.880-887. 2014. Available from: <http://dx.doi.org/10.1590/S1806-66902014000500003>. Accessed: Jun. 13, 2020.

BESEN, R. M. et al. Práticas conservacionistas do solo e emissão de gases do efeito estufa no Brasil. Scientia Agropecuaria, v.9, n.3, p.429-439, 2018. Available from: <http://dx.doi.org/10.17268/ sci.agropecu.2018.03.15>. Accessed: Jun. 12, 2020.

BLANCHART, E. et al. Long-term effect of a legume cover crop (Mucuna pruriens var. utilis) on the communities of soil macrofauna and nematofauna, under maize cultivation, in southern Benin. European Journal of Soil Biology, v.42, p. 136-144, 2006. Available from: <https://doi.org/10.1016/j.ejsobi.2006.07.018>. Accessed: Jun. 13, 2020.

BRUNO, C. L. DA S. et al. Plantas de cobertura no sistema plantio direto. Rev. Conexão Eletrônica, v.14, n.1, p.611-619, 2017.

CASARIL, C. E. et al. Fauna edáfica em sistemas de produção de banana no Sul de Santa Catarina. Revista Brasileira de Ciências Agrárias, v.14, n.1, p.5613, 2019. Available from: <http://dx.doi. 10.5039/agraria.v14i1a5613>. Accessed: Jun. 13, 2020.

CREPALDI, R. A. et al. Formigas como bioindicadores da qualidade do solo em sistema integrado lavoura pecuária. Ciência Rural, v.44, n.5, p.781-787, 2014. Available from: $<$ https://doi.org/10.1590/S0103-84782014000500004>. Accessed: Jun. 13, 2020.

DRAY, S. et al. The ade4 package- II: two-table and K-table methods. R News, v.7, n.2, p.47-52, 2007.

DONAGEMA, G. K. et al. Manual de métodos de análises de solos. 2. ed. Rio de Janeiro, RJ: Embrapa Solos, 2011. 230p. Documentos Embrapa Solos, 132. Available from: <https:// www.infoteca.cnptia.embrapa.br/bitstream/doc/990374/1/ ManualdeMetodosdeAnilisedeSolo.pdf $>$. Accessed: Jan. 22, 2020.

GAZOLA, C. V. et al. Benefícios das plantas de cobertura e plantio direto em sistemas de agricultura orgânica regenerativa - uma visão geral. Rev. Conexão Eletrônica, v.14, n.1, p.474484, 2017.

JERNIGANA, A. B. et al. Legacy effects of contrasting organic grain cropping systems on soil health indicators, soil invertebrates, weeds, and crop yield. Agricultural Systems, v.177, p.1-21, 2020. Available from: <https://doi.org/10.1016/j.agsy.2019.102719>. Accessed: Jun. 13, 2020 
KEENEY D. R.; BREMNER J. M. Use of the Coleman model 29 A analyser for total nitrogen analysis of soils. Soil Science, v.104, n.5, p.358-363, 1967.

LAVELLE et al. Soil function in a changing world: The role of invertebrate ecosystem engineers. European Journal of Soil Biology, v.33, p.159-193, 1997.

MAUNSELL, S. C. et al. Springtail (Collembola) assemblages along an elevational gradiente in Australian subtropical rainforest. Australian Journal of Entomology, v.52, p.114-124, 2012. Available from: <https://doi.org/10.1111/aen.12012>. Accessed: Jun. 13, 2020.

MORAES, M. T. et al. Benefícios das plantas de cobertura sobre as propriedades físicas do solo. In. TIECHER, T. (Org) Manejo e conservação do solo e da água em pequenas propriedades rurais no sul do Brasil: práticas alternativas de manejo visando a conservação do solo e da água. Porto Alegre, UFRGS. 2016. 186p.

PEREIRA, M. G. et al. Manual de coleta e identificação da fauna edáfica, $2018.44 \mathrm{p}$.

REDIN, M. et al. Plantas de cobertura de solo e agricultura sustentável: espécies, matéria seca e ciclagem de carbono e nitrogênio. In. TIECHER, T. (Org) Manejo e conservação do solo e da água em pequenas propriedades rurais no sul do Brasil: práticas alternativas de manejo visando a conservação do solo e da água. Porto Alegre, UFRGS. 2016. 186p.
SCORIZA, R, N. et al. Efeito do cultivo de plantas de cobertura sobre a fauna edáfica. Revista Brasileira de Agroecologia, v.11, n.4, p.310-318, 2016. Available from: <http://revistas. abaagroecologia.org.br/index.php/rbagroecologia/article/ view/17575/12333>. Accessed: Jun. 13, 2020.

SILVA, J. et al. Fauna do solo em sistemas de manejo com café. Journal of Biotechnology and Biodiversity, v.3, n.2, p.59-71, 2012 .

TORRES, J. L. R. et al. Produção de fitomassa por plantas de cobertura e mineralização de seus resíduos em plantio direto. Pesquisa Agropecuária Brasileira, v.43, n.3, p.421428, 2008. Available from: <https://doi.org/10.1590/S0100204X2008000300018>. Accessed: Jun. 19, 2020

TIVELLI, S. W. et al. 2010. Adubação verde e plantio direto em hortaliças. Revista eletrônica Pesquisa e Tecnologia, v.7, p.17. Available from: <http://www.aptaregional.sp.gov.br/acesseos-artigos-pesquisa-e-tecnologia/edicao-2010/2010-janeirojunho/714-adubacao-verde-e-plantio-direto-em-hortalicas/file. html>. Accessed: Jan. 15, 2020.

YEOMANS, J.; BREMNER, J. M. A. rapid and precise method for routine determination of organic carbon in soil. Communications in Soil Science and Plant Analysis, v.19, p.1467-1476, 1988. Available from: <https://doi.org/10.1080/00103628809368027>. Accessed: Jan. 22, 2020. 